〔農化注第 50 巻，第 9 号, p. 395 402, 1976]

\title{
酵素による銺油稌菌体量の定量および 菌体量の䤑造上の意味について
}

\author{
加藤 威, 小林邦男, 泉 保廣, 花岡嘉夫 \\ (キッューマン暂油株式会社関西工場研究課)
}

昭和 51 年 3 月 31 日受理

\begin{abstract}
An Enzymatic Method for the Estimation of the Mycelial Content of Shoyu koji and the Significance of its Content in Shoyu Production

By Takeshi KatoU, Kunio KoBaYASHI, Yasuhiro IZUMI and Yoshio HaNAOKA

Research Laboratory, Kansai Plant, Kikkoman Shoyu Co., Ltd.,

Takasago Hyogo
\end{abstract}

\begin{abstract}
An enzymatic method was devised for the estimation of mycelial content of Shoyu koji and the significance of its content in Shoyu production was studied.

The crude enzyme preparation, containing $\beta-1,3$-glucanase and chitinase, was separated from the culture fluid of $B$. circulans (IAM 1165). This enzyme had the 1ytic activity on the cell walls of Asp. sojae X-816 and liberated N-acetylglucosamine. Determining the liberated $\mathrm{N}$-acetylglucosamine as a clue, mycelial content was calculated.

Correlation analyses of mycelial content vs. various indications for Shoyu production yielded following correlation coefficients, mycelial content vs. protease activity of koji : $0.693, * *$ vs. amylase activity of koji : $0.723, * *$ vs. degradation rate of total $\mathrm{N}$ in koji digestion $: 0.602$, ** vs. ratio of amino- $\mathrm{N}$ to total- $\mathrm{N}$ in koji digestion : 0.314 , vs. ratio of glutamic acid to total- $\mathrm{N}$ in koji digestion : 0.595 . **

As the result of contigency table tests, there existed no relation between spore formations of koji and either the mycelial content or the degradation rate of total-N.
\end{abstract}

(Received March 31, 1976)

\section{舶言}

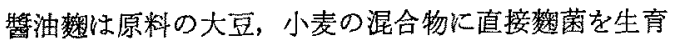
させ，これを食塩水とともに仕込むるのであるが，その 良否は整品品質, 原料の利用性に大きな影響を及汸すた め, 良い麴を得ることは製造上重要な問題となっている. しかしながら，良い棅の判定はむずかしく，現在はプロ テアーゼ，アミラーゼなど生成醳素の活性，あるいは胞 子着生の程度を意味する “花付” 等, いわ而接的方法

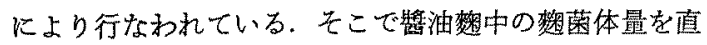
接定量し，麭良否の判定の一助としょうと考光た，

固体棦中の数菌体量の定量については，すでに報告が なされている。米数に和ける有馬ら(1)，大内ら(2)，俆油

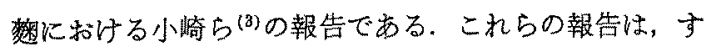

べて試料梖を酸分解し，婪菌細胞壁の成分であるキチン より生成するグルコサミンを定量指標としたものである が，原料の米，大豆，小麦よりの定量妨害物質を除去す る操作が煩雑である.

掘越ら ${ }^{(4)}$ によると, Bacillus circulans IAM 1165 は 及-1,3-・゙ルカナーゼ，扰よびキチナーゼを良く生産し， その培着液は棅菌（Aspergillus oryzae）細胞壁を特異 的溶解する。

本報告灶，B.circulans IAM 1165 の生成する䣼素を

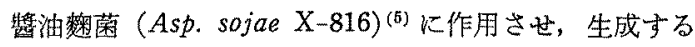
N-アセキルグルコサミンを指標として醬油眢中の菌体 量の定量を試み，ざらにその方法で求めた菌体量が䂾造 上に有する意味を考察するため, 菌体量と既存の各種䁔 造指標との相関関係を検詂したものである. 


\section{実 験 方 法}

\section{1. 定量法の検討}

\section{1. 溶菌酵素の調製}

i）掊地の調製：堀越らの培地 ${ }^{(4)}$ に隻じたが，前培琵 培地としてはグルコースを $10.0 \mathrm{~g} / \mathrm{l}$ 满て補強したるのを， 本培羙坛地としてはグルコースを除き，代りに後述する 方法で採取した碩菌菌系 (Asp.sojae X-816) を $30.0 \mathrm{~g}$ (wet weight)/l あて添加したものを使用した，数菌菌

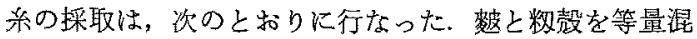

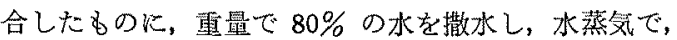
$120^{\circ} \mathrm{C}, 30$ 分加圧殺菌後, Asp. sojae X-816 の種整を接

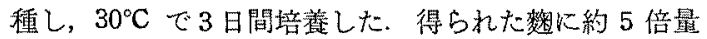

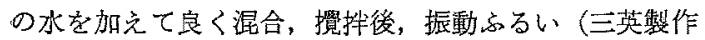
所制）でるるい分けした，150〜400※ッシュ区分に集 まる数菌菌系を採取し，充分に水洗後検鏡して，菌系の 欢であることを確諗した

ii ) B. circulans IAM 1165 の培養：前述の前培盖培 地を殺菌試験管，㟧よび坂ロコルペンに老れぞれ $10 \mathrm{ml}$ 和よび $100 \mathrm{~m} 1$ ずつ採り， $120^{\circ} \mathrm{C} ， 10$ 分間の加生殺菌を 行なった，次に常法に従い，B.circulans の1日金耳老

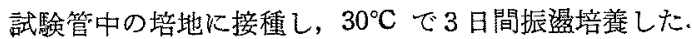
この1本を坂ロコルペン 1 本に接種し，同様に 3 日間蔚

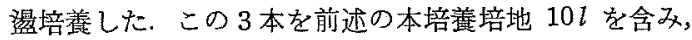
あらかじめ $120^{\circ} \mathrm{C} ， 30$ 分間の加圧殺菌它行なったジャ ーファーメンター（丸菱理化装置研究所 Disk Turbin Type, $20 l$ 容量) に接種し， $37^{\circ} \mathrm{C}$ で 3 日間通気䚌拌培

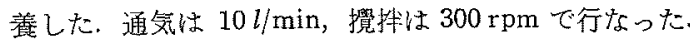

iii）醉素の調製：ジャーより排出した培養ブロスを， $15,000 \times g$ て連続遠心分離（トミー精工 No. $90 \mathrm{UV}$ 冷 凍遠心機）し，その上澄液に酼酸アンモニウムを $70 \%$ 鴒和あて添加後， $5^{\circ} \mathrm{C}$ で1夜放置した。生じた沈殿を $1500 \times g$ で再び連続遠心分離し，pH 7.0 Mcllvaine buffer $500 \mathrm{ml}$ に溶解後，1登夜 $5^{\circ} \mathrm{C}$ の水に対して透析し た. 次に，この透析内液の $40 \sim 60 \%$ 酝酸アンモニウム 飽和で沈股する区分を pH 7.0 McIlvaine buffer に溶 解し，蒸留水で允分透析後，凍結乾燥した，得られた粉 未溶菌酵素祭品とし，以後の実験に使用した，

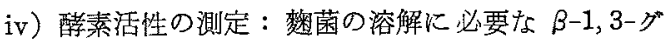
ルカナ一ゼ执よびキチナーゼの活性は，次のよらに測定 した。

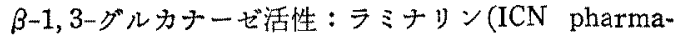

ceuticals Inc.) を $\mathrm{pH} 6.5$ McIlvaine buffer $\kappa 0.33 \%$ 西て溶解し，この $4.5 \mathrm{ml}$ 亿前述の溶菌酵素標品の $1 \%$

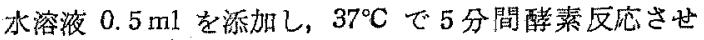
た。所定時間後， $100^{\circ} \mathrm{C} て ゙ 3$ 分間加熱して反応を止め， 塩酸括よび为性》ーがで pH 5.5 とし，全体を $20 \mathrm{ml}$ 定容とした。この $1 \mathrm{ml}$ 中の生成グルコース量をグルコ 一スオキシダーゼーパーオキシダーゼ法(6,7)で定量し，酵 素標品 $1 \mathrm{mg}$ 当りの生成グルコース量（ して酵装活性とした。 なお，反応 $\mathrm{pH} 6.5$ はラミナリン を基質とし，上述の方法で活性を求めた場合の至適 $\mathrm{pH}$ である。

キチナーゼ活性 : Hackman ${ }^{(8)}$ および Berger(9) $の$ 方 法に蕉じて調集したコロイドキチン $2 \mathrm{ml}$ 人，常用の I/10 甄度に調製した $\mathrm{pH} 7.0 \mathrm{McIlvaine}$ buffer $4 \mathrm{ml}$ と

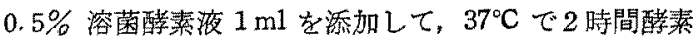
反応させた，所定時間後， $100^{\circ} \mathrm{C} て ゙ 3$ 分間加熱して反応 を停止させ，反応液を $0.65 \mu$ のメンブランフィルター で吸引滤過した．濾液中の N-アセチルグルコサミン (以後 G1cNAc と路导) を Morgan-EIson 法(10)で比色 定量し（124 形日立ダプルビーム分兆光度計），酵素標 品 $1 \mathrm{mg}$ 当りの生成 GIcNAc 量 ( $\mu$ mole) 煌算して酵 素活性とした。 な秥，反応 $\mathrm{pH} 7.0$ はコロイドキチンを 基質とし，pH 5.0 8.0を Mcllvaine buffer で 0.5 間 隔に調製し，上述の方法で活性を求めた場合の至適 $\mathrm{pH}$ である.また，McIlvaine buffer を常用の 1/10 濃度で 使用したのは，Morgan-Elson 法における発色反灾が至 適 $\mathrm{pH} 8.9^{(11)}$ で行なるれるよらにするためである。

\section{2. 試料の調製}

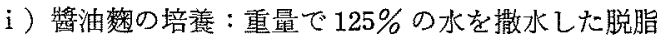
大豆を $120^{\circ} \mathrm{C} て ゙ 30$ 分閻加圧蒸煮し, 故冷後, 撤水前の 脱脂大豆と等量の炒謷割确小麦を加总て良く混合した。 これに Asp. sojae X-816 の種整を少量接種して，30

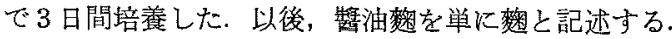

ii）喽中心微生物の採取：䊝中に存在する微生物で当 社中央研究所保存の Asp. sojae X-816, Bacillus subtilis, Micrococcus caseolyticus M 160(12) を，それらが 実際の製造過程で生育する環境と近似した培地で純粋培 責し，生育菌体を採取した。

Asp. sojae X-816: 脱脂大豆括よび炏謷小麦を 40 メ ッシュ以下儿粉研し，これらを等㫪ずつ混合した：これ に, その重量の約 4 倍の水（クロラムフェニコール 50 $r / \mathrm{ml}$ 含有) を加えて泥状とし，シャーレK分注後 $120^{\circ} \mathrm{C}$, 


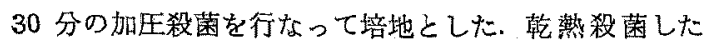
筆を用い, Asp. sojae X-816 の胞子をナイロン濾布上に

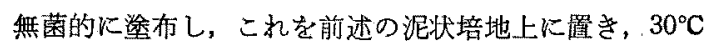
で3日間培亘した，濾布上に生青した菌体を集め，蒸留 水で 4 回洗浄後, 凍結乾燥した.

B. subtilis，M. caseolyticus M-160：前述の方法で培 養した新に 5 倍量の水を加方， $30^{\circ} \mathrm{C} て ゙ 4$ 時間放置後，

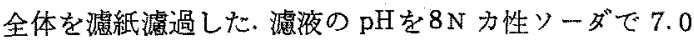
保製後， $120^{\circ} \mathrm{C}, 10$ 分間の加代殺菌を行ない，生ずる 沈殿を $15,000 \times g て ゙ 10$ 分間遠心分離し，さらにその上 澄液を $0.65 \mu$ のメンブランフィルターで殺菌試験管中 人無菌濾過し、これを培地とした。この培地へ，それぞ れのスラントより 1 白金耳市て接種し，30ㄷ，24 時間の 振璗培養を行ない，生育菌体を8000 × 分離した，以後蒸留水を用い，同様な遠心分離に上る洗 浄を 4 回くり返し，最後に菌体を谏結乾燥した。

3. 定量原理の確認： $80 \mathrm{~g}$ に $12 \%$ 食塩水 $250 \mathrm{ml}$ 特よびトルエン $10 \mathrm{ml}$ を㳢加し，ミキサーでホモゲナイ ズした後， $37^{\circ} \mathrm{C} て ゙ 2$ 日間消化した。このときの食塩濃 度は，約 $8 \%$ となる。は，消化スラリーの採取は先太 のピペットで行なったが，その粘性，括よびホモゲナイ ズの際にスラリー中へ巻き込なれる気泡等のため，採取 する絶対容量の正確さは期しがたい，従って，以下に記 すスラリーの採取容量は，すべて相齐値と見なし，採取 絶対量が必要な場合は後述するごとく，食塩量を基にし て行なった.

消化スラリ一の 2,4 拉よび $6 \mathrm{ml}$ を先太のピペット で採取し,東洋濾紙 No. 2 上で, その洗液が $250 \mathrm{ml}$ とな るまで水洗した，滤紙上の残渣を前述したごとく，常用 の 1/10濃度に調製した pH 7.0 Mcllvaine bufferでる れ発れ別個のL字管中へ洗い込み, その全容を $14 \mathrm{ml}$ と した，その中へ $0.5 \%$ の溶菌醉菜液 $1 \mathrm{ml}$ ずつを加克, $37^{\circ} \mathrm{C}$ で酵素反応させた. 反応時間が $1,2,3$ および 4 時 間のとき，各反応液より $3 \mathrm{ml}$ ずつを採取し，ただちに 反応を停止後, 東洋濾紙 No. 5 で濾紙濾過した. 濾液中 の生成 GlcNAcを Morgan-Elson 法で定量し， $585 \mathrm{~nm}$ 飞和ける各吸光度 (O.D.585 と略す) で表示した。な拉。 反分 $\mathrm{pH} 7.0$ は前述した Asp.sojae X-816 の乾燥菌体

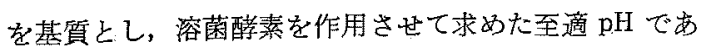
万.

4. 標準添加法による菌体量の推定： 前述ど和りホ モゲナイズした麵のスラリー $5 \mathrm{ml}$ ずつを 4 本の試験管

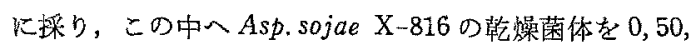
100 打よび $150 \mathrm{mg}$ 西て添加し， $37^{\circ} \mathrm{C} て ゙ 2$ 日間消化し た。以後，前述したごとく各消化液を滤紙上で水洗し， その残渣を $\mathrm{L}$ 字管中へ洗い込み, 各全容を $14 \mathrm{ml}$ とし た.この中へ $0.5 \%$ の溶菌䤃素液 $1 \mathrm{ml}$ ずつを添加して, $37^{\circ} \mathrm{C}$ で 2 時間䤃素反応させ，各々の生成 GlcNAc を定 嘿し，各O.D.585 で表示した。

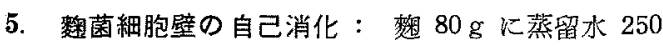
$\mathrm{m} 1$ 枋よびトルエン $10 \mathrm{~m} 1$ を添加し，だだににミキサー でホモダナイズ後，その $5 \mathrm{ml}$ ずつを 5 本の試験管に採 り、この中へそれぞれの食塩濃度が $0,5,10,15$ 拈よび $20 \%$ となるように結晶食塩を添加した. $37^{\circ} \mathrm{C} て ゙ 2$ 日間消 化した後，各々の消化液を前述ど打りに水洗し，その残 渣をL字管中へ洗い込み，各全容を $14 \mathrm{ml}$ とした。この 中へ $0.5 \%$ 溶菌䤃素液 $1 \mathrm{ml}$ お゙つを添加して, $37^{\circ} \mathrm{C} て$ 2 時間酵素反応させ，各ふの生成 GlcNAc を定量し， O.D.585 で表示した.

6. 共存物質の影響： 整に重量で約 5 倍量の水を加 克， $30^{\circ} \mathrm{C}$ で 5 時間抽出後，濾紙濾渦した，得られた濾 液をさらに $15,000 \times g$ で 10 分間遠心分缷し，その上澄 液に結晶食塩を涯加して，その濃度が $8 \%$ となる上うに

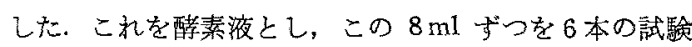
管に分注し，それぞれへ蒸煮脱脂大豆 $1 \mathrm{~g}$ ，炒謷割砕小 麦 $500 \mathrm{mg}$, 前二者の混合物, 㘧よび Asp.sojae X-816, B. subtilis, M. caseolyticus M 160 の各乾燥菌体 $75 \mathrm{mg}$

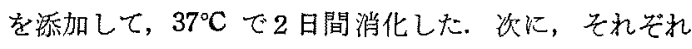
の消化残渣を $15,000 \times g$ で 10 分間遠心分離し，引专続 き同样な遠心分離による水洗を行なった啳，各残渣に $1 / 10$ 濃度の $\mathrm{pH} 7.0$ Mcllvaine buffer $14 \mathrm{ml}$ および 0.5 \%溶菌醳素液 $1 \mathrm{ml}$ ずつを添加して, $37^{\circ} \mathrm{C}$ で醉素反応さ せた． 2 時間後反応を停止させ， $15,000 \times g$ で 10 分間 の遠心分離を行ない, 各上澄液中の GlcNAc 定量し， O. D. 585 で表示した. な䄱，脱脂大豆，小麦およびAsp. sojae X-816 の供試量については，前述した愁然の消化ス ラリー $5 \mathrm{ml}$ 中に含委狆る妥当な推定量であるが, $B$. subtilis, M. caseolyticus M160の去れについては, 推 定量の約 10 倍の量でるる。

\section{II. 菌体量の培造上の意味}

1. 菌体量の異なる秘の培養：培養方法は前述ど括 りとしたが，菌体量が広籁用で翼なるようにするため，

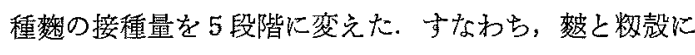
培羕したAsp.sojae X-816 の種策をふるい分けし，145 
メッシュ以下に集中する胞子を集め, 接種後の胞子数が $5 \times 10^{4}, 2.5 \times 10^{5}, 5 \times 10^{5}, 2.5 \times 10^{6}$ および $5 \times 10^{6}$ 個/g となるようにした．各段階とも4サンプルずつとし，計 20 サンプルを $30^{\circ} \mathrm{C} て ゙ 3$ 日間培養した。

2. 数水分の測定： 上述の麴各 $5 \mathrm{~g}$ を精秤し， $105^{\circ} \mathrm{C}$ で 6 時間乾燥した場合の各隇量分を贱水分とした。

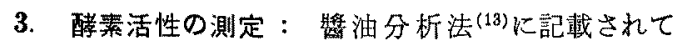
いる方法を一部改変して行なった．麴 $10 \mathrm{~g}$ に蒸留水 200

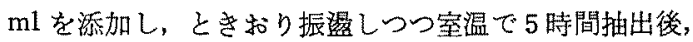
東洋濾紙 No. 2 で濾過し，その滤液を醉素液とした。

プロテアーゼ活性：カゼイン-275 nm 吸取法 ${ }^{(14)}$ で行 なった. pH 7.0 Mcllvaine buffer に溶解した $0.6 \%$ カ ゼイン (Hammarsten Merk) 溶液 $5 \mathrm{ml}$ K，前述の酵

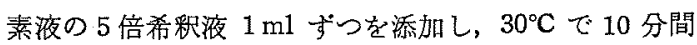

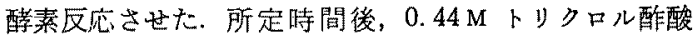
溶液 $5 \mathrm{ml}$ を派加して反応を停止させ，約 20 分放置し て蛋白質の沈殿を完全にした，沈殿を東洋濾紙 No. 5 で 濾別し，濾液の $275 \mathrm{~nm}$ に拈ける吸光度 (O.D.275) 在測 定した．測定試料の O. D . 275 から，それぞれのブランク

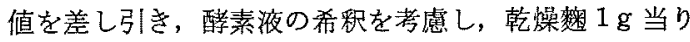
の O.D. ${ }_{275}$ 深算して表示した.

アミラーゼ活性：可溶性デンプンを基質とした場合の 生成還元糖を測定して, 醉素活性とした. $30 \mathrm{~m} 1$ 容の試 験管に $0.2 \%$ 可溶性デンブン水溶液 $1 \mathrm{ml}, 0.02 \mathrm{M} \mathrm{pH}$ 4.8 酶酸緩衙液 $0.5 \mathrm{ml}$ および 10 倍希釈の醭素液 0.5 $\mathrm{ml}$ を添加し， $30^{\circ} \mathrm{C} て ゙ 10$ 分間醳素反応させた。 これに ソモギ一の銅試薬 $2 \mathrm{~m} 1$ を加えて反応を停止させ，以後 Somogyi-Nelson の常法 ${ }^{(15)}$ 汇従い, 生成環元糖を 500 $\mathrm{nm}$ に括ける吸光度 (O. D. 500 ) で測定した. プロテアー ゼ活性之同様，それ旮れのブランク值を差し引き，希釈 倍率を考虑し, 乾燥械 $1 \mathrm{~g}$ 当りの O. D. 500 に換算して表 示した.

4. 数菌体量の測定： 後述する考察の項に記した方 法で行なった。

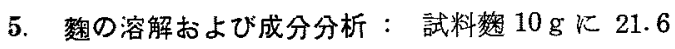
\%食塩水 $125 \mathrm{ml}$ とトルェン $5 \mathrm{ml}$ を添加し， $37^{\circ} \mathrm{C} て ゙ ~ 14$ 日間消化した．次にその全体をミキサーでホモゲナイズ した後, 一部を東洋㵽紙 No.2 で濾過し, 濾液中の総窒 素 (TN と略)，アミノ態窒素 (Amino-N と略)，グル タミン酸（G1u-A と略）を舫油分析法に従って5分析し た. 京た原料窒素の溶解性は, 次のように算出した. 各

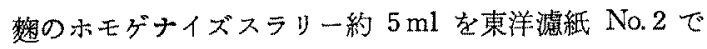

濾過洗浄し，その洗液 を $250 \mathrm{ml}$ K定容とした．洗液和 よび滤維上の残渣の総窒素をそれぞれ $A$ 和よびBとした 場合， $A /(A+B) \times 100$ をる。て原料窒素の溶解性とし た.

6. 相関分析： 菌体量 vs. 各種锼造指標, す广かち プロテアーゼ活性, アミラーゼ活性, 原料窒素の溶解 性, 溶解液の Amino-N/TN, Glu-A/TN につ各相関 図を描きそれれそれの相関保数を算出した。

7. いわゆる “花付”之菌体量および原料空素の溶解 性との関係：いわゆる“花付”とは这を肉眼観祭した 場合，槒菌胞子に起因する黄色の程度を意味するが，こ の花付と菌体量和上び原料空素の溶解性との関係につき 検討した. I-2-i の方法で無作為に培盖した 1 対の鵴を 試料とし，いずれか一方の謎に着目して花付の良否，お よび測定菌体量の多少に関する順位付を行なった。すな わら花付, 菌体量ともに 1 位の場合には $(1,1)$, 花付は 1 位, 菌体量は 2 位の場合には $(1,2)$, 同様に $(2,1)$, $(2,2)$ 等の符号をその䴯に付した，同様のことを 1 日 1 対ずつ 24 対の枆について行ない，各符号の発生回数に つき $2 \times 2$ 分割表を作成した. このデータをるとに独立 性に関する $\chi^{2}$-検定を行ない，花付と菌体量が独立であ るか否かる検討した，また，花付と原料空素の溶解性に ついても, 同様なことを行なった。

\section{結果および考察}

\section{I. 定量法の検討}

溶菌醉素 5 口ットの $\beta-1,3-$ グルカナーゼ括よびキチ ナーゼ活性の平均は，それぞれ $2.22 \mu \mathrm{mole} / \mathrm{mg}, 0.23$ $\mu \mathrm{mole} / \mathrm{mg}$ で，その標準偏差は 0.66，0.09であった。

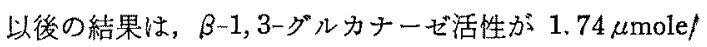
$\mathrm{mg}$ キチナーゼ活性が $0.29 \mu \mathrm{mole} / \mathrm{mg}$ の標品用いて 行なった実駼結果である。

\section{1. 定量原理および標準添加法による菌体量の推定：} 基質の整スラリーを 2,4 および $6 \mathrm{ml}$ と変化させた場合 の各反応時間に和ける GlcNAc の生成量を Fig. 1 亿示 した. 图に示すごとく，各反応時間とも，生成 GlcNAc と供試スラリー量とは直線関係を有し，後述する Table II の結果（GlcNAc は菻菌体のみに由来する）も考虑 すると，一定時間における GlcNAcの生成量は, 基質菌 体濃度に比例すると判断された，従って，このG1cNAc の生成量を比較することにより, 試料間の猌菌体量の比 較が可能となった，以後の実娩汇和いては適度な吸光度 
を考慮し，反沁時間をすべて 2 時間に統一した。

次に，菌体量の絶対量の推定を標準添加法で行なった

一例を Fig. 2 に示した。供試スラリー中の大豆，小麦

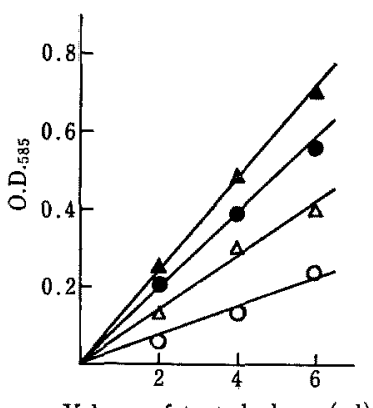

Volume of tested slurry $(\mathrm{ml})$

Fig. 1. Liberation of $\mathrm{N}$-Acetylglucosamine by Lytic Enzyme.

Shoyu koji was homogenized and digested at $37^{\circ} \mathrm{C}$ in the concentration of $8 \% \mathrm{NaCl}$. After two days, $2,4,6 \mathrm{ml}$ of digested slurries were washed with water on separate filter papers. Using $\mathrm{pH} 7.0 \mathrm{McIlvaine}$ buffer, each residue on the paper was transferred to test tube and the total volume of each was adjusted to $14 \mathrm{~mL}$. Adding $1 \mathrm{ml}$ portions of $0.5 \%$ lytic enzyme solution, mixtures were incubated at $37^{\circ} \mathrm{C}$ in the presence of toluene. Liberated $\mathrm{N}$-acetylglucosamine was determined by Morgan-Elson method at hourly intervals. $-\mathrm{O}-1 \mathrm{hr}$, $-\triangle-2 \mathrm{hr},-3 \mathrm{hr},-4 \mathrm{hr}$.

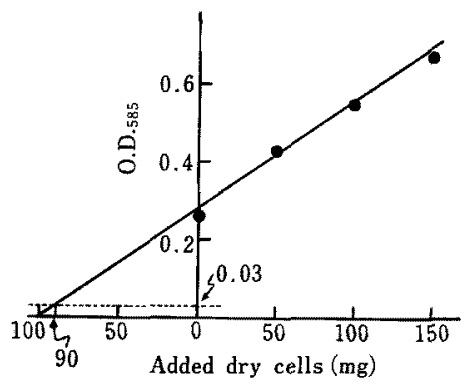

Fig. 2. Estimation of Mycelial Content by the Method of Standard Additions.

$0,50,100,150 \mathrm{mg}$ of dry cells of Asp. sojae $\mathrm{X}-816$ were separately added to $5 \mathrm{ml}$ of homogenized slurries of $k o j i$ and the mixtures were digested at $37^{\circ} \mathrm{C}$ in the concentration of $8 \% \mathrm{NaCl}$. In similar procedures as Fig. 1, each residue was transferred to test tube and incubated with the lytic enzyme at $37^{\circ} \mathrm{C}$. After two hours, liberated $\mathrm{N}$-acetylglucosamine was determined by Morgan-E1son method. Confer Table II for the meaning of the base line (0.03).
に由来する O.D.585 は後述するごとく 0.03 であるため これを考慮するとこの例の場合は，スラリー $5 \mathrm{ml}$ 中 に90mgの乾㯒菌体が含まれていると推定された。この 値を基にして乾熶菌体含量（\%)を計算するわけであるが 前拈した理由で採取容量は絶対的ではないため，代りに 食塩量を手掛かりとして次のよらに行なった。

硝酸銀規定液で定量した洗液 $250 \mathrm{ml}$ ，すなからスラリ 一 $5 \mathrm{ml}$ 中の食塩量は $0.3 \mathrm{~g}$ であった。一方, 試料赖 80 $\mathrm{g}$ の消化の際に使用した $12 \%$ 食塩水 $250 \mathrm{ml}$ 中の食塩 量は $30 \mathrm{~g}$ であるため，この中に含まれる乾燥菌体量は $9 \mathrm{~g}$ と計算された，さらに，棅の水分 $30 \%$ を考艮して， 乾物換算すれば 12.8 となり，小崎ら(3)の報告とほぽー 致した。な拉，この標準添加法はすべての陚料について は行なわず，他の試料については，Fig. 2 より求めた O. D. $=1.0$ 当りの蒜燥菌体量 $(=360 \mathrm{mg})$ をるとにして 計算した。

2. 䴯菌の自己消化：Asp. sojae X-816 を培前して

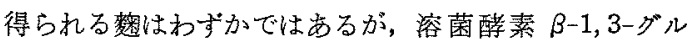
カナーゼ蛙よびキチナーゼ活性を示す(16). 従って, 定量

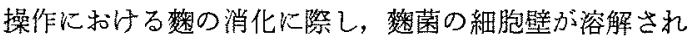
ることがあれば定量誤差を生ずる。これを防止するた

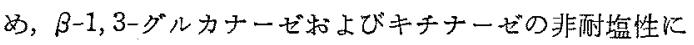
着目し，麴の消化に $12 \%$ 食程水を使用したわけである が，その效果を Table I に示した，巽なる 5 種の食绵 濃度で消化した各残浩より生成する GlcNAc 量はほとん

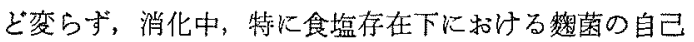
消化は無視し得るるのと判断した。

\section{3. 共存物啠の影嘫：本定量法は GlcNAc を定舅指}

Table I. Autolysis of Asp. sojae X-816 in Digesting Shoyu koji at Various Concentrations of $\mathrm{NaCl}$

\begin{tabular}{cc}
\hline $\begin{array}{l}\text { NaCl concentration in } \\
\text { digesting sample koji }(\%)\end{array}$ & O.D.585 \\
\hline 0 & 0.190 \\
5.00 & 0.190 \\
9.60 & 0.202 \\
14.16 & 0.202 \\
18.80 & 0.216
\end{tabular}

Homogenized slurries of $k \circ j i$ were digested at $37^{\circ} \mathrm{C}$ for two days in various concentrations of $\mathrm{NaCl}$. In similar prcedures as Fig. $1,5 \mathrm{ml}$ portions of digested slurries were washed with water and each residue was transferred to test tube and incubated with the lytic enzyme at $37^{\circ} \mathrm{C}$. After two hours, liberated $\mathrm{N}$-acetylglucosamine was determined. 
Table II. Effects of Coexistings in Shoyu koji on the Estimation of Mycelial Content

\begin{tabular}{lc}
\hline \multicolumn{1}{c}{ Sample } & O.D.585 \\
\hline Cooked soybeans & 0.02 \\
Roasted wheat & 0.02 \\
Cooked soybeans +roasted wheat & 0.03 \\
Aspergillus sojae X-816 & 0.23 \\
Bacillus subtilis & 0.02 \\
Micrococcus caseolyticus M160 & 0.02 \\
\hline
\end{tabular}

One $\mathrm{g}$ of cooked soybeans, $500 \mathrm{mg}$ of roasted wheat, mixture of cooked soybean $(1 \mathrm{~g})$ and roasted wheat $(500 \mathrm{mg}), 75 \mathrm{mg}$ of dry matters of Asp. sojae X-816, M. caseolyticus M 160, and $B$. subtilis were incubated with the enzyme solution extracted from Shoyu $k o j i$ at $37^{\circ} \mathrm{C}$ in the concentration of $8 \% \mathrm{NaCl}$. After two days, washed with water by centrifugation at 15,000 $\times g$, each residue was incubated with $15 \mathrm{ml}$ of lytic enzyme solution for two hours at $37^{\circ} \mathrm{C}$. Liberated $\mathrm{N}$-acetylglucosamine was determined by Morgan-Elson method.

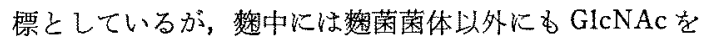
含むものがある。すなわら，一般細菌はその細胞壁に N-アセチルムラミン酸と結合して大量に，大豆はその

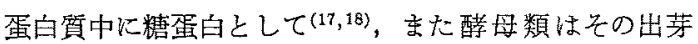
痕にキチン(19) として，それぞれ少媈ずつ含有している。 従って，溶菌酵素によって，これらの物質より GlcNAc が溶出するならば，定量法は不正確なるのとなる、これ を確認するための実験であるが，釈中の醉母類は注とん

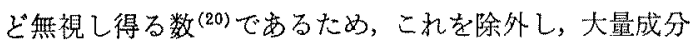
である小麦を加えて実験を行なった，結果 (Table II) に示すと拈り，Asp. sojae X-816 の O. D.585 が王倒的に

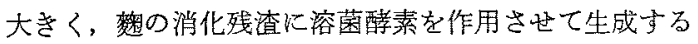
GlcNAcは，ほとんど釈菌のみに由来すると判断した。 次に共存物質の影響で岁るが，細菌類の O.D.685 は前述 した実験条件を考慮すると完全に無視し得るが，大豆， 小麦の混合物の O. D.585 少(17,18)であることを考慮すると，その值0.03はG1cNAc に起因するとは思われないが，菌体量の正確な推定に は，この值をブランクとして控除する必要があると判断 した.

4. 結論：以上の結果から，次の結論に達する，䊝

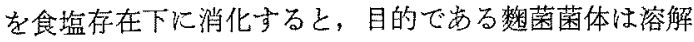
されずに残椬中に残る。この残椬は帟菌のみでなく，原 料等，他物質からの溶解残渣をも含えでいるが，これに 溶菌醏素を作用させると，数菌体のみより GlcNAc が生 成する。この GlcNAcの一定時間における生成量は基質

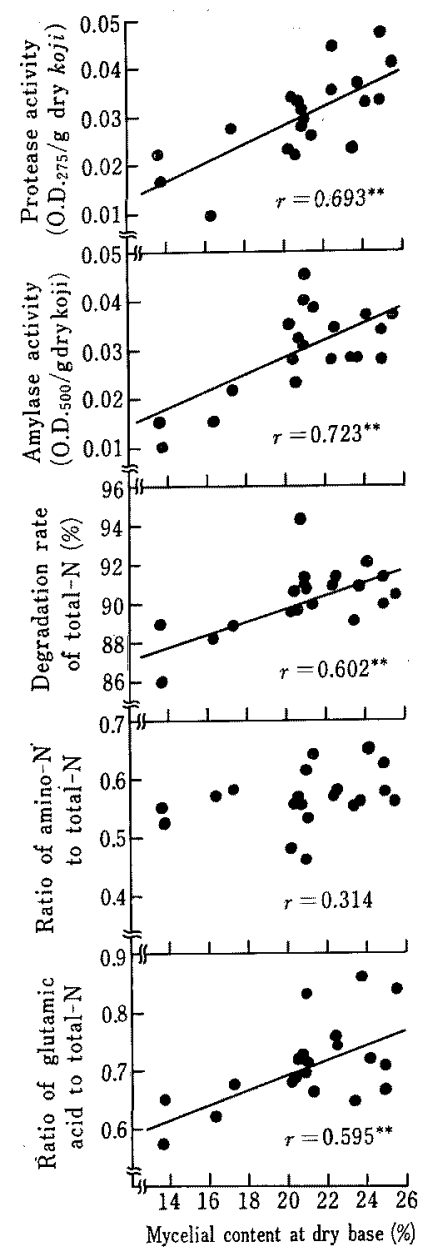

Fig. 3. Correlation analyses of Mycelial Content vs. Various Indications for Shoyu production.

Twenty samples of koji were cultured so that the mycelial content varied each other. With these samples, correlation analyses of mycelial content $v s$. various indications for Shoyu production were performed. Correlation coefficient was shown in each scatter diagram. ** significant at $1 \%$ level.

菌体濃度に比例するため，これを定量することにより試 料中の数菌体量が定量できる.

具体的定量法は，次の上らに要約される。数 $80 \mathrm{~g}$ K $12 \%$ 食塩水 $250 \mathrm{ml}$ 拈よびトルエン $10 \mathrm{ml}$ を添加後, ミキサーでホモゲナイズして $37^{\circ} \mathrm{C} て ゙ 2$ 日間消化する. この消化スラリー $5 \mathrm{ml}$ を先太のピペットで採取し，東 洋濾紙 No. 2 上で, その洗液が $250 \mathrm{ml}$ となるをで水洗 する.滤紙上の残渣を，常用の1/10 濃度に調製した $\mathrm{pH}$ 
7.0 Mcllvaine buffer を用いてL字管中へ完全に洗い込

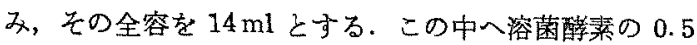
\%水溶液 $1 \mathrm{ml}$ を添加して $37^{\circ} \mathrm{C}$ で 2 時間醳素反応させ, 反応停止後全体を東洋滤縒 No. 5 で濾過し, 濾液中の GlcNAc を定最する．得られた O. D. 585 かららブランク O. D. $585(=0.03)$ を控除し， O. D. $585=1.0$ 当りの乾燥菌 体量 $360 \mathrm{mg}$ ，楼スラリー $5 \mathrm{ml}$ 中の食掹量，杽の消化 の祭に使用した全食塩量，扣よび焂の水分とから，前述

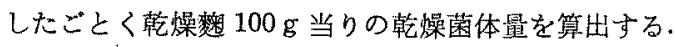

\section{II. 菌体量の䁔造上の意味}

1. 菌体量と酾造指標との相関：モデル的に培着し た椈 20 種の菌体量と各種釀造指標との相関図, 括よ び算出された相関係数を Fig. 3 亿示した. 菌体量 vs. Amino-N/TN については相関関係が認められなかった が，他の菌体量 vs. プロテアーゼ，アミラーゼの活性， 原料窒素の溶解性，Glu-A/TN については，1\%危険率 でそれぞれ正の相関関係を示した。この結果は，菌体量 が多くなれば各種醸造指標は好ましい力向へ移行するこ とを示し，常識的ではあるが，原料の整化の程度が進さ ほど良いことを示した．な拉，相関分析は相対値の比較 で足りるため，Fig. 3 の菌体量の算出には，前述のブラ ンク値の控除は省略した。このため, 図中の菌体量値は $1 \%$ 程度高い值を示している。

2. 花付と菌体量および原料窒素の溶解性：“花付” は樬の良否を判定する重大な指標の1つとされている が，これが真実良否を表現し得るものかを検討した，花 付之菌体量扣よび原料窒素の溶解性以関する $2 \times 2$ 分割 表を，Table III 特よびIV に示した，㖨無仮説を“花 付々菌体量江無関係”, “花付と原料空素の溶解性は無 関保”としてYates の修正式に従って $\chi^{2}$ を求めると，

Table III. $2 \times 2$ Contigency Tables about the Ranks of Spore Fomations and Mycelial Content

\begin{tabular}{lrrr}
\hline $\begin{array}{l}\text { Mycelial } \\
\text { content }\end{array}$ & \multicolumn{2}{c}{ Spore formations } & Total \\
\cline { 2 - 4 } & 1 st & 2 nd & \\
\hline 1 st & 8 & 4 & 12 \\
2 nd & 6 & 6 & 12 \\
Total & 14 & 10 & 24 \\
\hline
\end{tabular}

After fixing the ranks of spore formations and mycelial content in a pair of koji, a contigency tables was constructed with 24 pairs about the both ranks of either koji. Chi-square test for independence was performed. $\chi=0.171$ $<\chi_{0}$ (region of rejection) $=3.84$. Therefore the hypothesis could not be rejected.
Table IV. $2 \times 2$ Contigency Tables about the Ranks of Spore Formations and the Degradation Rate of Total-N

\begin{tabular}{lrrr}
\hline $\begin{array}{c}\text { Degradation } \\
\text { rate of } \\
\text { total-N }\end{array}$ & \multicolumn{2}{c}{ Spore formations } & Total \\
\cline { 2 - 3 } & 1 st & 7 nd & \\
\hline 1 st & 8 & 3 & 15 \\
2 nd & 6 & 3 & 9 \\
Total & 14 & 10 & 24 \\
\hline
\end{tabular}

After fixing the ranks of spore formations and the degradation rate of total- $\mathrm{N}$ in a pair of $k o j i$, a contigency tables was constructed with 24 pairs about the both ranks of either koji. Chi-square test for independence was performed. $\chi=0.020<\chi_{0}$ (region of rejection) $=3.84$. Therefore the hypothesis could not be rejected.

それ華れ 0.171 ，特よび 0.020 となり，自由度 1 の $\chi^{2}$ 分布の有意水準 $5 \%$ の棄却域深入らず，仮説は车却さ

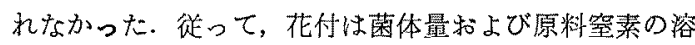
解性の兩者に対して独立であると判断された．花付不良

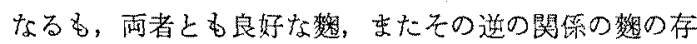
在を示唆し，樬花付は菌体量および原料窒素の溶解珄を 完全に表現しているとはいいきれず，これを絶対視する ことは危険と思われた。

$$
\text { 要 的 }
$$

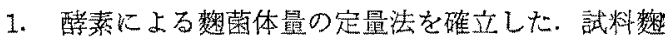
を食塩存在下に消化すると，目的である㹼菌菌体は溶解 されずに残椬中に残る、この残渣は畨菌体のみでなく， 他物質よりの溶解残椬をむ含んでいるが，これにB.

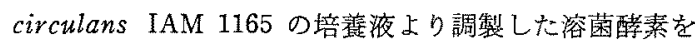
作用ざると，猌菌体のみより N-アセチルグルコサミ ンが生成する。この Nーアセチルグルコサミンの一定時 間における生成量は基質菌体濃度に比例するため,これ を測定することにより試料中の棃菌体量が定量でさる。 具体的定量法は，考察 I-4 D項に記した。

2. 上述の方法で定量した棅菌体量が醸造上に有する

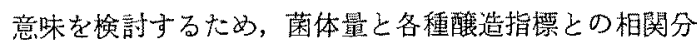
析を行ない，次のよらな結果を得た。

菌体䑁 vs. プロテア一ゼ活性 $0.693 * *$, vs. アミアー ゼ活性：0.723**，vs. 原料窒素の溶解性：0.602**, vs. Amino-N/TN : 0.314, vs. Glu-A/TN : 0.595**.

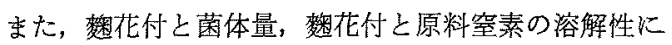

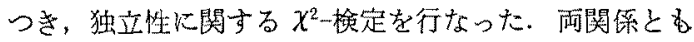
互いに独立であることが判明し，従来，花付は䊝良否の 重大な指摽の1つとして报われているが，これを絶対視 
することは危険と思対た。

終りにのでみ，発表を許可された安藤貴夫工場長をは じめ本社役買各位， $\chi^{2}$-検定をご指導いただたた当社中 央研究所，森修三氏，また多大なご助力をいただいた当 研究課，杉井泰利氏に深謝いたしま子。

(1) K. Arima and T. Uozumi : Agr. Biol. Chem. 31. 119 (1967).

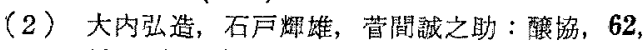
1029 (1967)

（3）小崎道堆，北原覚雄：食工誌，21，38（1974）.

（4）掘越弘毅：囦化，41，R21 (1967).

（5）井口信義：農化，29，73 (1955).

（6）田主澄三，川村信一郎：香川大限学報，21，110 (1970).

（7）奥田 瀾，三輪一智: 蛋白質 核酸 醉素，17， 216 (1972)

(8) R. H. Hackman : Australian J. Biol. Sci, 7, 168 (1954).
(9) L. R. Berger and D. M. Reynolds : Biochim. Biophys. Acta, 29, 522 (1958).

（10）鈴木 匡，松村 剛，山科郁男：多栯生化学, 第 1 巻, 共立出版, 1969, p. 55 .

(11) J. L. Reissing, J. L. Storminger and L.F. Leloir : J. Biol. Chem., 217, 959 (1955).

（12）北原成之，石塚善太郎：酸工，47，1 (1967).

（13）日本紧油研究会編：酱油分析法，1966, p. 63.

（14）赤掘四郎編：醉素研究法，第 2 巻, 朝倉書店, 1955, p. 237.

（15）安滕鋭郎，寺山 宏，西沢一俊，山川民夫：生 化学研究法, 第 1 巻, 朝倉蓄店, 1967, p. 256 .

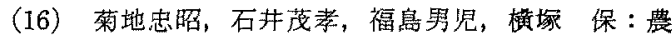
化, 45, 235 (1971).

(17) I. Koshiyama: Agr. Biol. Chem., 31, 874 (1967).

（18）中浜敏雄編：鰧油酸造の最新の技術と研究，日 本酶造協会, 1972, p. 8.

(19) E. Cabib and B. Owers : J. Biol. Chem., 246, 152 (1971).

（20）芳賀 宏：調味科学， 20(1)，13 (1973). 